\title{
THE GREAT MARBLED GODWIT.
}

\author{
+ Limosa Fedoa, Linn.
}

\section{PLATE CCCXLVIII.-MaLe and Female.}

This fine bird is found during winter on all the large muddy flats of the coast of Florida that are intermixed with beds of racoon-oysters. As the tide rises it approaches the shores, and betakes itself to the wet savannahs. At this season it is generally seen in flocks of five or six, searching for food in company with the Tell-tale, the Yellow-shanks, the Long-billed Curlew, and the White Ibis. While feeding, it probes the mud and wet sand, often plunging its bill to its whole length, in the manner of the Common Snipe and the Woodcock. It is fond of the small crabs called fiddlers, many of which it obtains both by probing their burrows, and running after them along the edges of the salt meadows and marshes. Sometimes you see it wading in the water up to its body, and when about to lose ground, it rises and extends its wings, still continuing to search for fry, until forced to fly off by the increased depth of the water, when it alights on the shore and recommences its operations. While feeding on the banks, it appears to search for food between and under the oysters with singular care, at times pushing the bill sidewise into the soft mud beneath the shells. Towards the middle of the day, the separate flocks come together, assembling on some large sand-bar, where they remain for hours, trimming their plumage, after which many of them continue some time motionless, standing on one leg. Suddenly, however, they are all seen to stretch their wings upwards, their bleating notes are heard, and the next moment the flock rises, and disperses in small parties, each of which proceeds in a different direction in search of food.

Few birds are more shy or vigilant than the Great Marbled Godwit. It .watches the movements of the gunner with extreme care, particularly while in small flocks, in which case it rarely happens that one can approach them, and they are more commonly shot by coming unawares over the concealed sportsman. When in large flocks I have known them to be neared, and killed in great numbers. On such occasions, they walk towards each other, until they are quite close, when they stand still. Then is the time for the gunner, who has driven them before him as it were, to the extremity of a 
mud or sand-bar, to fire with a certainty of obtaining something worth his trouble, for besides the number killed by his first shot, he is likely to commit equal havoc with the second, as they fly off in a dense mass.

On the 31st of May, 1832, I saw an immense number of these birds on an extensive mud-bar bordering one of the Keys of Florida, about six miles south of Cape Sable. When I landed with my party, the whole, amounting to some thousands, collected in the manner mentioned above. Four or five guns were fired at once, and the slaughter was such, that I was quite satisfied with the number obtained, both for specimens and for food. For this reason, we refrained from firing at them again, although the temptation was at times great, as they flew over and wheeled round us for awhile, until at length they alighted at some distance and began to feed. Those which we killed were plump, and afforded excellent eating. I was much surprised to find these Godwits so far south, but next morning, when none were to be seen excepting some wounded birds which we had not pursued, I concluded that the flock, which was the largest I have seen, had merely alighted there for the day.

The flight of this bird is regular and rather quick, although in the latter respect not to be compared with that of the Curlews. When flying to a considerable distance, or migrating, they usually proceed in extended lines, presenting an irregular front, which rarely preserves its continuity for any length of time, but undulates and breaks as the birds advance. The beat of their wings is regular, and they rarely utter any cries on such occasions.

This species enters the United States, on its return from its northern breeding-grounds, about the middle of August, and probably travels along the coast at that period as well as when proceeding northward, none having been seen by me or my party in Labrador or Newfoundland, and their passage having been observed only on the Atlantic shores of Nova Scotia, and the whole line of our coast, on different parts of which some of the flocks alight, and rest for a few weeks, both in spring and in autumn. I may add, that I never saw one of these birds beyond the distance of a few miles from the sea-shore.

Great Marbled Godwit, Scolopax Fedoa, Wils. Amer. Orn., vol. vii. p. 30.

Limosa Fedoa, Bonap. Syn., p. 328.

Limosa Fedoa, Great Marbled Godwit, Swains. and Rich. F. Bor. Amer., vol. ii. p. 395.

Great Marbled Godwit, Nutt. Man., vol. ii. p. 173.

Great Marbled Godwit, Limosa Fedoa, Aud. Orn. Biog., vol. iii. p. 287; vol. v. p. 590.

Male, $16 \frac{1}{2}, 28 \frac{1}{2}$. Female, $20 \frac{1}{2}$.

Passes in spring from Texas along the coast, in immense flocks, to Massa- 
chusetts, and apparently across the land, to the Saskatchewan, where it breeds. None seen in Labrador. A few breed in South Carolina, perhaps also in Texas. Not observed in the Western Country. In autumn returns southward beyond the limits of the United States.

Adult Male.

Bill very long, slender, sub-cylindrical, tapering to the obtuse point, slightly recurved. Upper mandible with the dorsal line slightly curved upwards in its whole extent, the ridge convex, the sides with a narrow groove extending almost to the point, the edges rather obtuse, the tip very slightly enlarged. Nostrils basal, lateral, nearer the edge than the dorsal line, small, linear, pervious. Lower mandible with the angle very long and extremely narrow, the dorsal line slightly recurved, the sides with a narrow groove extending almost to the end, the edge rather blunt, the tip obtuse.

Head small, oblong, compressed. Neck rather long, slender. Body slender. Feet long and slender. Tibia bare for about a third, anteriorly scutellate; tarsus long, slender, covered anteriorly with numerous scutella, scutellate behind also, laterally reticulate; toes small, slender, scutellate above, flat beneath, broadly marginate, the anterior connected at the base by webs, of which the outer is much larger; first toe very small, second slightly shorter than fourth, third little longer. Claws small, compressed, slightly arched, obtuse, that of middle toe with the inner edge curved outwards and thin.

Plumage soft and blended, on the fore part of the head very short, on the neck short and almost downy, on the abdomen and sides full, on the back moderate; all the feathers oblong and rounded. Wings rather long, very acute, narrow; primaries tapering, the first longest, the second little shorter, the rest rapidly graduated; secondaries incurved, obliquely rounded, the inner elongated and tapering. Tail short, even, of twelve narrow, rounded feathers.

Bill dull flesh-colour in its basal half, the rest blackish-brown. Iris brown. Feet bluish-grey. The head and neck light yellowish-grey, the throat without markings, the upper part of the head streaked with blackish-brown, as is the hind-neck, the markings there being fainter. The rest of the upper parts spotted and barred with brownish-black and greyish-yellow. Alula and primary coverts brownish-black, as are the outer webs of the three first quills, those of the other primaries, and both webs of the secondaries, reddish-ochre, all more or less mottled with dusky, and the primaries of that colour towards the end, but with the terminal margins whitish; the inner secondaries barred like the back, as are the tail-feathers. Breast, abdomen, and lower surface of wings, light reddish-yellow, the axillar feathers of a deeper tint, the sides faintly barred with dusky.

Length to end of tail $18 \frac{1}{2}$ inches, to end of wings $19 \frac{1}{2}$, to end of claws 21 ; VoL. V. 
wing from flexure 9 ; tail $3 \frac{1}{2}$; bill along the ridge $4 \frac{6}{12}$, along the edge of lower mandible $4 \frac{4}{12}$; bare part of tibia $1 \frac{7}{12}$; tarsus $2 \frac{10}{12}$; middle toe $1 \frac{8}{12}$, its claw $\frac{4 \frac{1}{12}}{12}$.

\section{Adult Female.}

The female is considerably larger than the male, but is similar in colouring, the lower parts of a less bright buff.

Length to end of tail $20 \frac{1}{2}$ inches, to end of wings $21 \frac{1}{2}$; bill 5 .

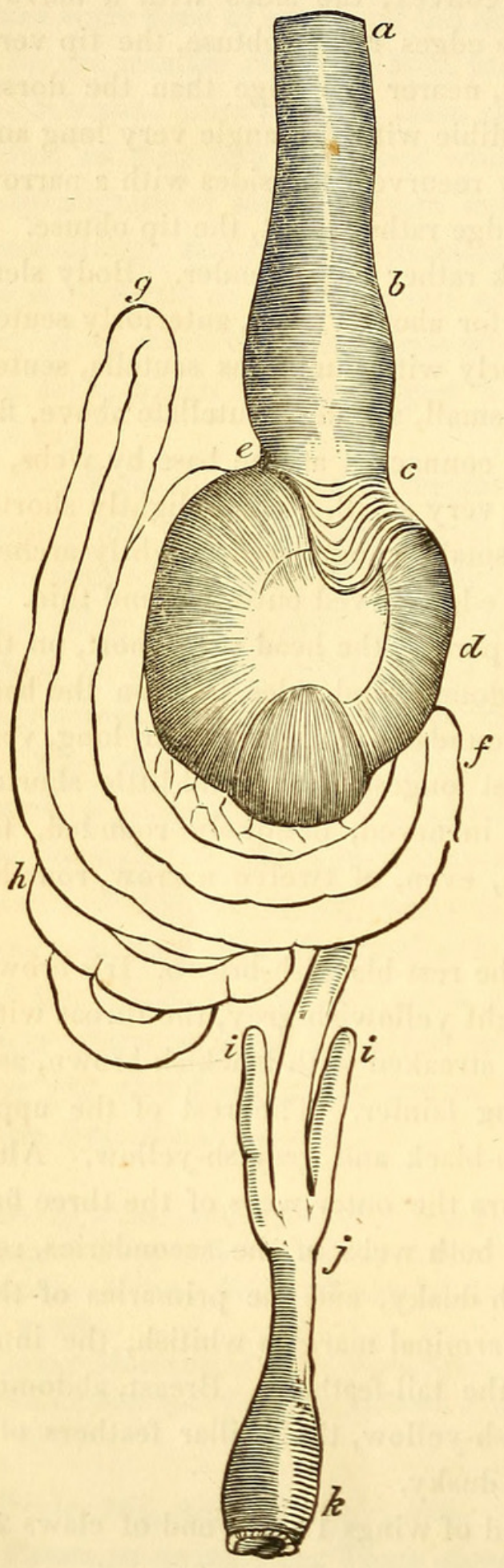

The inner edge of the middle claw is usually broken, which is a common circumstance in birds that have it very thin, but there are no regular serratures or notches upon it.

Adult Male. Length to end of tail $16 \frac{1}{2}$ inches, to end of wings 17 , to end of claws 20; extent of wings $28 \frac{1}{2}$; wing from flexure $8 \frac{3}{4}$; tail $3 \frac{2}{12}$; bill along the ridge $3 \frac{10}{12}$, along the edge of lower mandible $3 \frac{9}{12}$; bare part of tibia $1 \frac{9}{12}$, tarsus $2 \frac{9}{12}$; hind toe $\frac{1}{2}$, its claw $\frac{2}{12}$; second toe $1 \frac{3}{4}$, its claw $\frac{3}{12}$; third toe $1 \frac{5}{12}$, its claw $\frac{4}{12}$; fourth toe $1 \frac{2 \frac{1}{1}}{12}$, its claw $\frac{2 \frac{1}{2}}{12}$.

Palate flat, narrow, with two longitudinal papillate ridges, and four series of very large papillæ, terminating anteriorly in a single ridge. The edges of the mandibles flat. Tongue very long, 2 inches 1 twelfth, trigonal, tapering to a point, concave above, with two series of large papillæ, its base emarginate and papillate. The upper mandible is entirely destitute of motion; the lower with a joint on each side, as in the Herons. Width of mouth $4 \frac{1}{2}$ twelfths. Essophagus, $a b c, 6 \frac{1}{4}$ inches long, at the commencement $\frac{1}{2}$ inch in width, prèsently contracting to 4 twelfths, and so continuing as far as the proventriculus, which is 7 twelfths in breadth. Stomach, $c d e$, of an oblong form, 1 inch 4 twelfths in length, 9 twelfths 
in breadth; its lateral muscles moderately strong, the tendons broad and radiated; the epithelium dense, thick, with numerous longitudinal rugæ. Its contents are remains of small shell-fish. Proventricular glands small and very numerous, forming a belt 10 twelfths in breadth. Intestine, $e f g h j k$, 2 feet 6 inches long; it curves at first in the usual manner, passes forward to above the heart, then runs backward, and forms seven turns; its width from $4 \frac{1}{2}$ twelfths to 3 twelfths. Rectum, $j k$, very short, being only $1 \frac{1}{4}$ inches in length; cœca, $i i, 9$ twelfths in length, $1 \frac{1}{2}$ twelfths in width; the cloaca, $k$, an oblong dilatation, 5 twelfths in width.

Trachea $4 \frac{3}{4}$ inches long, 3 twelfths in breadth, its rings very feeble, 132, with a single dimidiate ring. Bronchial half rings 18 . The lateral muscles strong; the sterno-tracheal moderate; a single pair of slender laryngeal muscles going to the first bronchial half ring.

\title{
THE H U D SONIA N GODWIT.
}

\author{
4 Limosa hudsonica, Lath.
}

\section{Plate CCCXliX.-Adult Male and Young Female.}

This species, which is of rare occurrence in any part of the United States, is scarcely ever found farther south along the coast than the State of Maryland. I had never seen it in the flesh, until I went to Boston in 1832, when I found specimens of it in the market late in September. An old gunner in my employ brought me eight or ten in the course of a month, but they were all young birds. From one of them my son drew the figure in the plate. While I was at Pictou Professor MacCulloch presented me with a pair of adult birds in beautiful plumage. When we were on our way towards Labrador, the fishermen and inhabitants of the Magdeleine Islands, who gave the name of Curlews to the Godwits, assured me that this species breeds there in some marshes at the extremity of the principle island, and that they were in the habit of killing them as soon as they were able to fly, when they were considered excellent food. We saw none, however, on our voyage farther north, and in Labrador and Newfoundland nobody seemed to know them. 


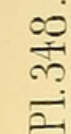

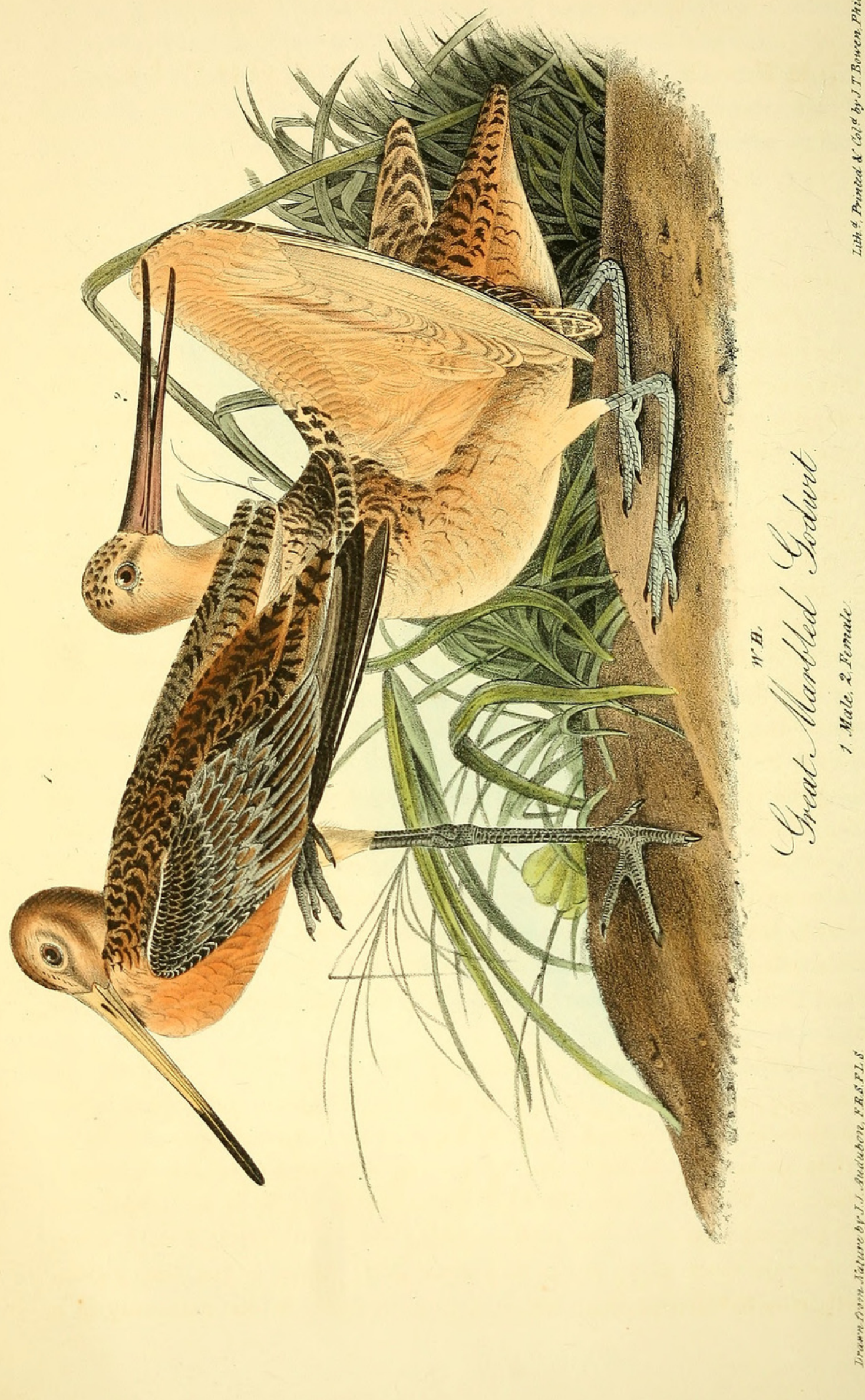




\section{$2 \mathrm{BHL}$ Biodiversity Heritage Library}

Audubon, John James. 1842. "The Great Marbled Godwit, Limosa fedoa [PI. 348]." The birds of America : from drawings made in the United States and their territories 5, 331-335. https://doi.org/10.5962/p.319461.

View This Item Online: https://www.biodiversitylibrary.org/item/124982

DOI: https://doi.org/10.5962/p.319461

Permalink: https://www.biodiversitylibrary.org/partpdf/319461

\section{Holding Institution}

Smithsonian Libraries

\section{Sponsored by}

Biodiversity Heritage Library

\section{Copyright \& Reuse}

Copyright Status: NOT_IN_COPYRIGHT

This document was created from content at the Biodiversity Heritage Library, the world's largest open access digital library for biodiversity literature and archives. Visit BHL at https://www.biodiversitylibrary.org. 